\title{
Older Workers in Changing Social Policy Patterns
}

\author{
NATHALIE BURNAY \\ Département des sciences politiques, sociales et de la communication, Facultés Notre-Dame de la Paix, \\ Namur, Belgium \\ Unité de sociologie et d'anthropologie, Université catholique de Louvain, Belgium
}

\begin{abstract}
Compared to other European countries, the employment rate of older workers in Belgium is rather low. This paper argues that one of the most relevant factors underlying the problems of this low employment rate in Belgium is the social policies directed at older workers. Indeed, when unemployment became a widespread phenomenon in the1970s and 80s, early-retirement schemes were designed to alleviate the financial implications on an aging workforce. The government encouraged anyone over 50 to leave the labour market through early retirement schemes, unemployment payment programs, medical retirement, and career breaks. These practises were based on a wide consensus of government, business, and workers.

However, for some years now, international organizations have been concerned about the viability of pension systems and their ability to achieve their objectives. In recent years, different factors have led policy makers to rethink this policy. But changing the trend and keeping people on the job has proven more difficult than foreseen. The transformations of public policies begun at the dawn of the 21st century radically changed the balance between the state, workers, and employers, who had all previously seen early retirement as favourable. This paper also tries to show how early retirement is not simply a desire to escape, but can also be explained as an aggression against the person by the labour market. Leaving professional life early thus seems more to be a case of necessity, in fact not a choice at all, but an obligation, or even a sacrifice, and must be seen in the perspective of professional duties and their evolution.
\end{abstract}

\section{Context}

Compared to other European countries, the employment rate of older workers in Belgium is rather low. In fact, until recently there had been a trend of decreasing participation in the labour market for workers over the age of 55. In 1960, 85\% of men from 55 to 59 years of age were active in the labour market; in 1980, this proportion had decreased to $74 \%$ and in 1997 the proportion further decreased to 49\% (data from Eurostat, 1998, as cited in Romans, 2007). A similar decrease was observed for men in the age group of 60 to 64 : from $71 \%$ in 1960 , to $40 \%$ in 1980 
and to $18 \%$ in 1997. In 2006, however, the statistics show a small increase as compared to 1997: 53 and 20\% for men of 55 to 59 years of age and those 60 to 64 years respectively. In the female labour market participation was very low until the late nineties: about $20 \%$ for women of 55 to 59 years of age, and approximately $5 \%$ for women 60 to 64 . The proportions reached 31 and 9\% respectively in 2005. Yet there remains a substantial difference in labour participation between older male and female workers.

These low levels of activity are explained by the situation faced by Belgium in the crisis of the 1970s. During the 1970s and 80s the rate of unemployment evolved within a context of major industrial upheaval and large scale restructuring and downsizing. The government policy to deal with the rising unemployment from about 1975 on, strongly favoured the young unemployed to the detriment of the older unemployed and even older workers (Simoens, 1980). The government encouraged anyone over 50 to leave the labour market through early retirement schemes, unemployment payment programs, medical retirement and career breaks. Additionally, reinterpretation of certain regulations regarding poor working conditions allowed others to leave work. These practises were based on a wide consensus of government, business, and workers. The federal government took in hand the direct costs of payments to the older unemployed and those taking early retirement, and the indirect costs through subsidies to businesses.

However, for some years now, international organizations have been concerned about the viability of pension systems and their ability to achieve their objectives. In Belgium, like in the European Union, the government introduced, in the beginning of the 2000s, a series of measures aimed at encouraging older people to remain in or to re-enter the labour market. In recent years different factors have led policy makers to rethink this policy. In fact, these transformations obviously raise questions about the relationship between older workers and social justice and correspond with the expansion of liberalism. Justice, within this context, demands that economic rewards and societal resources are linked to ambition, effort, and prudent exercise of individual choice, rather than, for example, to citizen status (Armstrong, 2006, as cited in Brodie, 2007, p.103). This model also assigns personal responsibilities, rather than collective social problems (Beck \& Beck-Gernsheim, 2002, pp. 22-26; Brodie, 2007, pp. 103-104).

But changing the trend and keeping people on the job has proven more difficult than foreseen. The balance between public policies, trade unions and older workers is breaking now. This paper discusses the results of this changing social policy pattern in terms of well-being and intention to leave the labour market.

\section{Retirement and Well-being}

From the perspective of New Institutionalism (Esping-Andersen, 1990; Hall, 1993; Hall, \& Soskice, 2001; Pierson, 1998), early departure from the labour market needs to be understood not simply as a personal choice but rather as a public policy question. It is in fact the "social benefits" system that encourages particular behaviour in individuals by offering or withdrawing employment opportunities for those over 50 (Guillemard, 2002; Guillemard, 2003). Belgian social protection 
policies reflect the continental model (a combination of state, private, semi-private, parastatal and NGOs that provide benefits) where generous unemployment benefits coexist with many possibilities of early withdrawal from the labour market and very limited systems which encourage and integrate the older employee. Thus older workers are condemned to inactivity at the end of their careers. In this way, the model cannot help but create widespread early retirement (Guillemard, 2003).

The development of a political model characterized by "marginalization and relegation" has consequences for the resolution of conflicts generated, for example, in the case of large-scale layoffs, but also the way in which early retirements are handled. This approach creates a feeling in the individual that the process is normal and an anticipation of retirement in the worker. We then see a whole culture of early retirement develop as norms and values evolve which are associated with the age of the employee. Social norms develop alongside the practise of early retirement which is more and more common, as well as the perceived legitimacy of these practises. The creation of acknowledged procedures and practises seals the social contract between the state, the worker (and their union) and the employer. We then see a real change in the social perception and place of workers, linked to their age.

The results below show how much these legal changes are accepted socially, even by the older workers themselves. The data were gathered within the Panel Study of Belgian Households (PSBH,), ${ }^{1}$ a longitudinal research project providing questionnaire data from 1992 to 2002. The study population consisted of 5,790 subjects, $^{2}$ divided into four age groups: less than 30 years of age, 30 to 39, 40 to 49 and 50 to 65. Employment status was categorized into five groups: stable job, temporary job, insecure job, unemployed, and pre-retired (only applicable in the oldest group).

To evaluate subjective well-being, the following outcome variables were assessed: sociability (leisure activities and membership in an association), life satisfaction, and mental health. Table 1 summarizes the outcome variables and their indicators (data from 2002).

Table 1. Concepts, dimensions, and indicators.

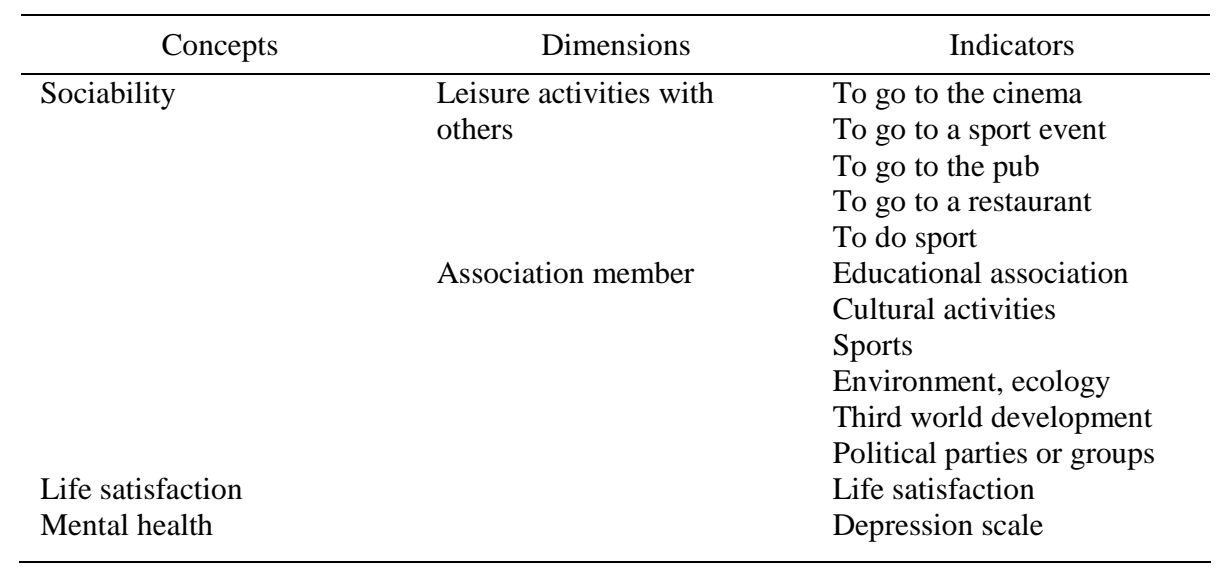


The concept of sociability can be divided into three dimensions (Gallie \& Paugam, 2000; Centre d'études des revenus et des coûts [CERC], 1993). Primary sociability refers to the immediate family: the presence of a partner or live-in children contributes to tight social relationships (not studied here). Secondary sociability describes the number of informal contacts with the extended family and mutual leisure activities. Tertiary sociability refers to the membership of one or more associations or to the participation in certain leisure activities. Since social isolation can be assessed by the number of social activities and contacts with family and friends, only secondary and tertiary sociability components were assessed within the context of this article.

Life satisfaction was assessed by a single question. Mental health was assessed by the Health and Daily Living Form Global Depression Scale (Moos, Cronkite, \& Finney, 1990). The following variables were also taken into account in the analyses: gender, education level, income, and family composition. The outcome variables were compared across employment statuses, using logistic regression analysis, with the stable job group as the reference category. ${ }^{3}$

Table 2 brings up two important elements. Firstly, as often mentioned in the literature, the experience of unemployment has a destructive impact on the individual (Eisenberg \& Lazarsfeld, 1938; Hepworth, 1980; Jahoda, 1979; Paugam \& Russell, 2000; Rosenberg, 1965). Whether in terms of sociability, personal happiness, or mental health, these indicate that the unemployed have greater difficulties than those in a stable job. Secondly, and more importantly in the present study, after the age of 50 this tendency is no longer significant. These unemployed benefit from a special status that means that they resemble more an early retired person than a younger unemployed person. This special status created in 1985 means that the requirement to enrol as a job seeker is waived, and that social benefits are increased for seniority. These measures permit the older unemployed, in periods of high unemployment, to withdraw from the labour market in the same way as does early retirement. The general principle is: after a year of unemployment a 50 year old can ask to obtain "older unemployed" status at which point they are no longer required to enrol as job seekers or go for weekly cheques to the employment office. In addition, while keeping their unemployed status, these unemployed people can begin self-employed work on a part-time basis (outside of normal working hours); this is not normally permitted for unemployed adults. These unemployed people are not counted in official statistics. This special status is in fact a kind of recognition by society that it is almost impossible for the older worker to re-enter the labour market. These measures are accepted by public opinion on the reasoning that by having worked for many years, these unemployed people have fulfilled their moral obligation to society. Thus we see in the above statistics the positive impact that this status of "older unemployed" has on those concerned.

An understanding was established between political decision makers, unions, workers, and the business community. In the case of business owners they can thus easily reduce the number of senior employees when restructuring the business or when salaries are too high (in Belgium salaries are strongly linked to seniority). 
Table 2. Odds Ratios for Well-being

Odds ratios for having some kind of leisure activities (data from 2002, $n=5790$ ).

\begin{tabular}{lllll}
\hline Employment status & $<30$ yrs & $30-39$ yrs & $40-49$ yrs & $50-65$ yrs \\
\hline Stable Jobs & Reference & Reference & Reference & Reference \\
Temporary Jobs & 0.75 (n.s.) & 0.89 (n.s.) & 0.67 (n.s.) & 0.70 (n.s.) \\
Insecure Jobs & 0.72 (n.s.) & 1.98 (n.s.) & 0.52 (n.s.) & 1.00 (n.s.) \\
Unemployment & $0.30^{* * *}$ & $0.38 * * *$ & $0.45^{* *}$ & 0.97 (n.s.) \\
Pre-retired & - & - & - & $1.26^{* *}$ \\
& & & & \\
\hline
\end{tabular}

Odds ratios for being a member of an association (data from 2002, $\mathrm{n}=5759$ ).

\begin{tabular}{lllll}
\hline Employment status & $<30$ yrs & $30-39$ yrs & $40-49$ yrs & $50-65$ yrs \\
\hline Stable Jobs & Reference & Reference & Reference & Reference \\
Temporary Jobs & $1.27^{*}$ & 1.22 (n.s.) & $0.52^{* *}$ & 1.19 (n.s.) \\
Insecure Jobs & $0.52^{* * *}$ & 1.15 (n.s.) & 1.32 (n.s.) & 0.89 (n.s.) \\
Unemployment & $0.70^{* *}$ & $0.37^{* * *}$ & $0.48^{* * *}$ & $0.74($ n.s.) \\
Pre-retired & - & - & - & $1.35^{* *}$ \\
\hline
\end{tabular}

Odds ratios for having good life satisfaction (data from 2002, n=5652).

\begin{tabular}{lllll}
\hline Employment status & $<30$ yrs & $30-39$ yrs & $40-49$ yrs & $50-65$ yrs \\
\hline Stable Jobs & Reference & Reference & Reference & Reference \\
Temporary Jobs & 0.75 (n.s.) & 0.96 (n.s.) & 1.72 (n.s.) & $0.30^{*}$ \\
Insecure Jobs & $3.57^{*}$ & $4.22^{*}$ & 1.00 (n.s.) & $0.63^{*}$ \\
Unemployment & 0.99 (n.s.) & $0.71^{* *}$ & $0.72^{* *}$ & $1.47^{* *}$ \\
Pre-retired & - & - & - & $1.57^{* * *}$ \\
\hline
\end{tabular}

Odds ratios for not having mental health problems (data from 2002, $\mathrm{n}=5210$ ).

\begin{tabular}{lllll}
\hline Employment status & $<30$ yrs & $30-39$ yrs & $40-49$ yrs & $50-65$ yrs \\
\hline Stable Jobs & Reference & Reference & Reference & Reference \\
Temporary Jobs & 0.81 (n.s.) & 0.86 (n.s.) & 0.85 (n.s.) & $0.75^{*}$ \\
Insecure Jobs & $0.78^{*}$ & 0.99 (n.s.) & 0.61 (n.s.) & $0.66^{*}$ \\
Unemployment & $0.31^{* * *}$ & $0.22^{* * *}$ & $0.42^{* *}$ & $1.23^{*}$ \\
Pre-retired & - & - & - & $1.56^{* * *}$ \\
& & & & \\
$* \mathrm{p}<0.10,{ }^{* *} \mathrm{p}<0.05, * * *$ & &
\end{tabular}




\section{Changing Political Approaches at the Beginning of the 2000s}

Many international bodies have come to recognize the importance of age and have made it a priority. Since 1995, the OECD has sounded the alarm based on demographic changes: the financial ability to cover retirement and other social welfare services are put in serious doubt by costs that are growing exponentially. The aging of the population has worried international bodies that have seen the numbers of those active in the labour market and those in retirement permanently reversed. Increased life expectancy, when seen in relation to the shape of the rest of the age pyramid, means that there is a generation of retired people for whom money must be found. It is given this context that the OECD tries to promote "active aging” policies which remove all obstacles to continued economic activity with age, be it because of early retirement or forced retirement at a given age both of which discourage any activity after a certain age (OECD, 1995; 1998).

In 1999 the European Union recognized the question as a major political challenge. In its 1999 report "The European Labour Market in the Light of Demographic Change,” the 50-64 age group was recognized as being the principal reservoir of labour power for the future.

The Lisbon Summit (March 2000) proposed that member states implement employment policies with an overall objective "to bring the employment rate for people $15-64$ (presently $61 \%$ on average) to approach as nearly as possible $70 \%$ in 2010 and to arrange that women's participation in the labour market (presently 51\% on average) increase to $60 \%$ by 2010." 4 The Stockholm Summit (March 2001) confirmed the decision of the member states to reach full employment as a way to respond to "the challenge of an aging population." It established intermediate objectives for 2005, an employment rate of $67 \%$ for $15-64$ year old men and 57\% for women. But more importantly, an objective of a $50 \%$ employment rate was set for 55-64 year old men and women for 2010. Among other measures, there was a request for a report to specify how best to reach these objectives. Keeping older workers active was finally on the agenda.

At the beginning of the 2000s, the Belgian government, like the European Union, introduced a series of measures aimed at encouraging older people to remain in or to re-enter the labour market. In recent years, different factors have led policy makers to rethink this policy.

It is no longer the policy to reduce the rate of unemployment, but rather to increase the rate of employment. The aim is two-fold: continue with the existing retirement system while increasing the rate of employment (more contributions for retirement, therefore increased means to manage the deficit connected with the aging population), enhance the possibilities for business to best use the potential of experienced workers.

The Belgian program is based on three complementary objectives:

- $\quad$ a policy to prevent people leaving the employment market;

- a shorter work week and other improved conditions, to facilitate life for workers over 50 ;

- public policy measures to reinsert the older unemployed back into the employment market. 
The preventive policy was created by the government of the time to reduce the risk of early ejection from the employment market by reducing the principal factors of risk, for example the inability to adjust to new production processes and new technologies. To combat this, it was necessary to reinforce the possibilities of job changes as well as the offers of continuing education and training of older workers, often excluded supposedly because they will soon be leaving.

Some measures have also been taken to prevent layoffs of workers aged 45 or over, but this is done only as an informational initiative for employers. When an employee of over 45 is laid off, the employer must offer them help to find other work (outplacement, psychological aid, and evaluation of strengths and weaknesses). These measures to prevent exclusion from the job market are clear indications to the worker that they are responsible for their reinsertion in the job market. This aid is provided to assist in their job search, but in the end, it is the worker that has the responsibility to get back into the work force.

The final objective of the 1999 reform is clearly part of this policy to get older workers back in the job market. The special "older unemployed" status created in 1985 has been progressively revised. Conditions to enter the program have been narrowed and "back to work" programs developed. Tax breaks have also been added for businesses who hire unemployed older workers.

This change in policy begun by the federal governmental in 1999 has been continued and expanded since then. In the 2003 National Action Plan (Plan d'Action National - PAN), Belgium made active aging one of its priorities. This policy is expressed through 4 points:

1. Enrolling older unemployed as job seekers. Being enrolled means that the job seeker must accept any reasonable job offer until the age of 58. This seriously reduces the use of the special "older unemployed" status created in 1985 and favours remaining active in the job market;

2. Maintaining workers in the job market by improving their "employability." To do this, special tutoring programs have been developed to assist recycling older workers within their professional sphere. The government is promoting training for older workers and developing ways to validate their abilities and experience;

3. Financial advantages provided for both employee and employer also means keeping more senior workers in the job market;

4. Changes in attitudes are promoted through repeated awareness campaigns with the concerned parties.

The actions taken by the federal government vis-à-vis the management of the end of career show the difficulties encountered in trying to reconcile macro-economic and demographic shifts within existing public policy. Moreover, the Belgian legislature is expected to take into account all these local conditions and to still implement the directives imposed by the EU.

While changes in policy are undertaken to keep older workers in the job market, we see a transformation of the substance of the proposed measures themselves. Here too, the Belgian legislature follows the European recommendations, basing policy on the development of strategies to activate older workers and job seekers by promoting 
the assistance tailored as closely as possible to the individual's needs. The key elements of the European strategy indicate that the activation procedures must be individualized; the content cannot be based on a general national policy, on the contrary, it must be established on a case by case basis and respond to the needs and capacity of each. Rather than give relatively high unemployment benefits and invest to create employment, the objective is to upgrade the skills of the individual. Instead of protecting rights and employment, the approach is to provide the individual with the needed capabilities to find their way in the job market (Bonvin \& Burnay, 2000).

There is therefore a two pronged approach: the worker is held responsible for their own actions and leaving the job market is individualized. The older worker is left in charge of their own ongoing development, must keep themselves "employable," and negotiate with their employer the time and manner of their progressive retirement.

In 2005 the federal government, after long negotiations with union, social and business organizations and against fierce opposition, brought in the "Agreement for Solidarity between Generations” (Pacte de solidarité entre les générations). This text confirms and reinforces the two pronged approach previously set in motion. In a chapter which is clearly concerned with "active aging," the Belgian government:

- $\quad$ increases training programs, especially for older workers;

- $\quad$ reforms government regulations concerning mass layoffs (more restrictions in the use of early retirement as part of the social measures, proactive engagement with workers through the creation of employment action groups);

- $\quad$ raises the retirement age;

- $\quad$ adds limitations to early retirement;

- establishes the return of older unemployed to work, in particular by developing outplacement.

This tightening of controls, concerning the end of career and retirement, is not the result of any change in public opinion, which does not question the solidarity between generations, quite the opposite in fact. The unions, which have an important role in Belgium, put all their power and weight behind stopping these federal government reforms, though in fact there was little public protest when the vote was taken. The working public seems to be slowly accepting the idea that it's necessary to work longer if we wish to maintain the same level of social service provision. These changes are moving forward in a climate of social tension but in which public opinion seems resigned to the inevitable.

\section{Analysis of the Intentions to Leave Work and Retire}

The change of public policy begun at the dawn of the $21^{\text {st }}$ century radically changed the balance between the state, workers, and employers, who previously had all seen early retirement as advantageous. The legal changes were to support those in difficulty at the end of their career or those in situations of mass layoffs with important social impact. 
In a recent Belgian study of workers, ${ }^{5}$ the average age at which people wanted to retire was about 58, with two modal points, the most desired age was 60 chosen by $35 \%$ of those questioned, followed by the age of 55 for $30 \%$. The age of 65 , the legal retirement age in Belgium, was of interest to only $8 \%$ of those questioned. ${ }^{6}$ If we split the variable responses, (with either the cut off equal to or less than 59 or equal to and superior to 60 ) $48 \%$ of people want to retire at 60 or later and $52 \%$ before $(n=$ 748 , that is $92 \%$ of 816 workers). These results confirm earlier studies in France and Belgium. We see that there are numerous studies that show the common aspiration to retire before the legal retirement age. The French study Employment (Emplois) of 1996 shows that the vast majority (71\%) of retired people do not want to continue any professional activity (cited in Guillemard, 2003). In a recent Belgian study by a team at the Vrije Universiteit Brussel (Elchardus \& Cohen, 2003), the ideal age to end a working career was established at between 59 and 60 . The preliminary results of the SHARE Europe wide study show that France is one of the countries where the desire for an early retirement is most frequently expressed ${ }^{7}$ (Blanchet \& Debrand, 2005).

The intention to leave the job market early arises for several reasons. It is difficult to clearly delineate each element as there is a great deal of interaction among them. This kind of end of career is perceived as a positive change by the majority of workers and corresponds to their objectives, be they personal, family or social: related factors include the work situation of the partner, their involvement with their children or grand children, free time considerations for leisure activities (Hardy \& Hazelrigg, 1999; Schultz, Morton, \& Weckerle, 1998; Szinovacz \& De Viney, 2000).

Exiting the job market is thus explained by personal factors even though it is part of a larger social process. Financial constraints and health factors seem to be equally good predictors (Barnay \& Jeger, 2006; Feldman, 1994; Friedman \& Orbach, 1974; Gratton \& Haug, 1983; McGoldrick \& Cooper, 1980; Parker, 1980; SaurelCubizolles et al., 1999, Walker, 1985). The greater the importance of the financial needs in the family, less often the decision to leave the job market definitively is taken: the salary loss engendered by the change cannot be sustained by the household. Changes in health can also contribute to leaving work, especially if the work history involves a lot of heavy or difficult manual labour (Lund \& Borg, 1999). Health probelms are an important reason why people leave the workplace, either using the mechanisms in place for this, notably the invalidity benefits procedure, or through other available procedures. Exiting the job market for health reasons represents $12 \%$ of men and $8 \%$ of women in the case of rheumatic diseases and $7 \%$ and 5\% respectively in the case of cardiovascular disease (Molinié, 2006). There is however an important link between these types of retirement and the difficulty of the employment situation (Molinié, 2006). The family structure, more particularly the professional circumstance of the partner, is a determining factor in the decision making process (Szinovacz \& De Viney, 2000; Van Solinge \& Henkens, 2005).

The scientific literature illustrates that the reasons for quitting work do not rely solely on an individual's desires, while certainly important, there are also individual, familial or social constraints at play. Table 3, based on data from the CAPA study confirms this idea. 
Table 3. Main Reasons Expressed for Early Retirement (\%)

\begin{tabular}{l|l|l|l}
\hline Main Reasons & Men & Women & TOTAL \\
\hline $\begin{array}{l}\text { Health reasons } \\
\text { Professional reasons }\end{array}$ & 36.3 & 38.4 & $\mathbf{3 7 . 2}$ \\
$\quad$ Heavy manual labour & 6 & 7.4 & $\mathbf{6 . 6}$ \\
Stress or psychological pressure & 17.2 & 9.6 & $\mathbf{1 3 . 6}$ \\
Working hours & 4.1 & 2.7 & $\mathbf{3 . 4}$ \\
TOTAL professional reasons & 27.3 & 19.7 & $\mathbf{2 3 . 6}$ \\
Personal reasons & & & \\
TOTAL & 36.5 & 41.9 & $\mathbf{3 9 . 2}$ \\
\hline
\end{tabular}

The two main reasons for early retirement are not directly related to the conditions of work, but rather failing health and personal reasons. In fact, almost $40 \%$ of the workers surveyed (42\% of women, $36 \%$ of men) want to leave professional life early for reasons that are unrelated to the world of work itself. The general acceptance of the cultural model where work is not the principle element of personal identity thus finds its expression: other norms and widely shared values are more important to individuals. These lead to a preference to leave work early, which some call the “early retirement culture” (Guillemard, 2003, p.47).

But in addition to this aspiration to open new horizons, there also exists a second solid reason for this phenomenon, almost as important as the first: health considerations push nearly $37 \%$ of workers to consider early retirement. The subjective impression of one's good health tends to diminish significantly after 45: while $90 \%$ of workers state that they are in good health before the age of 45 , only $70 \%$ of those between 45 and 54 and nearly $75 \%$ of workers over 55 say the same thing. In a similar finding, less than $25 \%$ of those under 45 felt their health was poorer than five years previously while $40 \%$ of those over 45 felt this way. On the other hand, the actual work capacity seems not to be influenced by age: the capacity is estimated to be $90 \%$ of the optimum performance in all age categories. So, while the subjective appreciation of health may not be a significant factor in understanding a choice to retire early (see preceding discussion), declining health might justify a departure that is imposed by necessity. In this sense, it is a kind of non-choice.

These statistics help us better understand what is at stake at the end of the working life. People see their health as diminishing with age-except for those over 55. This fact, which seems contradictory, can be explained by the selection of those surveyed: only those over 55 and still in work answered our questionnaire, the others, probably in poor health, were not part of our sample. On the other hand, the perception of reduced health does not seem to affect work abilities. This happens as though the state of health, even when diminished, remains adequate to get the job done. Here we 
see that early retirement affects only those workers with significant health problems, that is to say health that is no longer adequate to deal with the necessities of the job.

Only $23 \%$ of the reasons given for early retirement are directly professional, and of those more than half concern psychosocial pressures. The weight of these psychosocial pressures, especially for men, reminds us of the importance of stress as identified previously. But even though only $23 \%$ of workers directly mention the importance of work related factors in explaining their desire to leave, we are still forced to group these strictly professional reasons together with those related to the subject of health. Clearly, if declining health is an identified reason, it is not possible to say that it is not, at least in part, due to the work environment and therefore indirectly connected to the world of work. It could be hypothesized that retirement for reasons of health is more socially acceptable than reasons that are more strictly professional.

Table 4 allows us to better understand the basis for early retirement. Each of three separate and independently conceived models is examined using Logical Regression Analysis: each reason invoked is a model. A high odds ratio indicates that the worker wanting to end their work career early has a tendency to cite this motive as the principle reason.

Different variables allow us to explain the motivations for early retirement, though some of these are not always significant in the overall motivation picture. These motivation variables have been reworked as four homogeneous blocks to better understand and describe them: socio-demographic variables, professional variables, health variables, and finally variables of sociability.

There are only two significant socio-demographic variables, sex and the level of education, though other variables were tested: number of children, the presence of a partner, type of housing, location of housing, etc. While the sex of the person had no significance in model 1 (health reasons), it did have a contrasting impact in models 2 and 3. More women than men cited "personal reasons" as their motivation for ending their working career, while it was just the contrary for "professional reasons."

The level of studies did not seem to come into the picture in model 2 dealing with "professional reasons" while it was pertinent in models 1 and 3 . Workers with post secondary studies cited health reasons less to justify their end of career. As the level of education goes down it appears that personal reasons are also less determinant to justify the choice made.

Professional variables also intervene in the choice of early retirement. Professional status is also an important factor. We see that labourers mention health reasons more than other groups, which is partially explained by a lower level of education. On the other hand, the more the status is that of a labourer, the less are the reasons for retirement likely to be professional. Model 3 seems to be very little influenced by the status.

As for the sector of activity, it seems to have an impact only on model 1: secondary sector workers plan to stop working early for health reasons more than those in the tertiary sector. Financial satisfaction influences only model 2, as workers that benefit from good financial conditions will raise professional reasons more often to justify their departure than those who are dissatisfied with their financial situation.

The subjective appreciation of health seems to be a significant variable in model 1 . This is quite logical: people who have health problems plan to end their working career for health reasons! However, the stress variable is more interesting, while it is 
Table 4. Logical Regression Analysis of the Reasons for Retirement

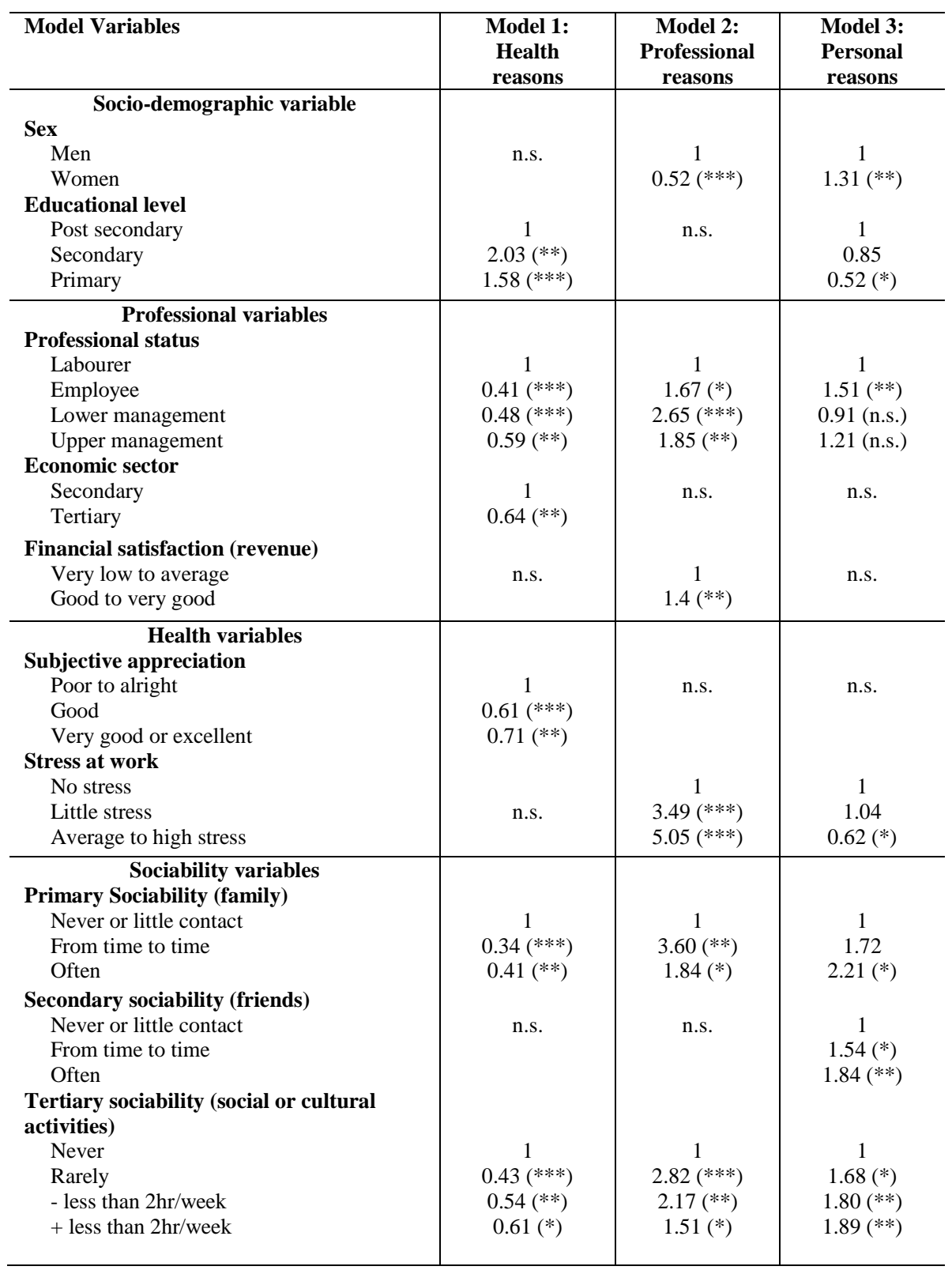

${ }^{*} \mathrm{p}<0.10,{ }^{* *} \mathrm{p}<0.05,{ }^{* * *} \mathrm{p}<0.01$, n.s. non relevant

not significant in model 1 , it is very important in model 2: stress is in fact the best predictor of early retirement for professional reasons. 
The last group of variables deals with sociability. These allow the indirect measure of the person's social relations outside the work sphere, that is to say, their symbolic investment outside the work environment. It is seen that primary sociability deals with family relations and more precisely the frequency of contact with the immediate family. While primary sociability restrains early retirement for health reasons, it is just the opposite in the case of models 2 and 3 . The higher the level of primary sociability, the higher is the level of risk of early retirement for professional or personal reasons.

In the same way, the higher the level of secondary sociability, the greater the risk is of early departure for personal reasons. This correlation is seen again for tertiary sociability: the more a person is involved in social or cultural associations, the more likely they are to leave their employment early for professional or personal reasons.

The foregoing analysis establishes three typical profiles. The first profile is workers who want to retire early for reasons of health. These are generally workers with low levels of education and who work as labourers. Their health is not good and has declined in the last five years. They have little contact with their families and participate very little in social or cultural activities. They can be described as socially withdrawn and isolated; their work and health are a weight on them. These are essentially workers that are tired and worn out but not especially stressed.

The second profile is of those workers that want to leave their professional life for reasons directly related to their professional life. Here we are talking about hyperactive men, who have developed strong primary sociability and many cultural activities, highly qualified and often upper management. Early retirement here is deeply rooted in the conditions of the work and more precisely the associated psychosocial pressures; the weight of stress is the principle reason.

The third profile is more feminine, and well educated. These workers develop many social relations, as much within the family circle as with a large group of friends. They are likely to get involved in social or cultural associations. Their symbolic investment is not centred only on their professional engagements. While little present in their lives, the stress they have is both professional and personal. The main consideration for these workers is to reconcile both personal and professional life, this equilibrium remains dynamic and can shift at any moment and lead to a retreat from the professional sphere. There is also a strong correlation between the high levels of sociability and working part-time which is probably chosen and not imposed.

These three profiles illustrate how leaving the work place early is not simply a wish for new horizons but is also an answer to various forms of aggression against the person, wear and tear at work, stress and other maladies are also predictive of an early exit from the workplace. Taken in this sense, the recent hardening by the Belgian government of legislation is contrary to this experienced distress. In recent years, changes in working conditions and intensified pressure in the workplace weigh heavily on the lot of individuals (Askenazy, Cartron, \& de Conick, 2006; de Nanteuil-Miribel, \& El Akremi, 2005; Gollac \& Volkoff, 2000). The following results (Table 5) show that the outcome variables, life satisfaction, leisure activities and mental health, decreased significantly during the eight year span of the PSBH study. In fact, older workers reported to have fewer organized activities were less satisfied with their life and had more mental health problems in 2002 as compared to 
1992 (data from Panel Study of Belgian Households, 1992-2002). These results could perhaps reflect a deterioration of working conditions over eight years.

Table 5. Evolution of the Outcome Variables between 1992 and 2002, Expressed as Odds Ratio with the 1992 Situation as Reference.

\begin{tabular}{l|l|l}
\hline Outcome variables & $\mathbf{1 9 9 2}$ & $\mathbf{2 0 0 2}$ \\
\hline Association member & reference & $0.94($ n.s. $)$ \\
Leisure activities & reference & $0.72(* *)$ \\
Life satisfaction & reference & $0.61(* * *)$ \\
Mental health & reference & $0.79(* *)$ \\
\end{tabular}

${ }^{*} \mathrm{p}<0.10, * * \mathrm{p}<0.05, * * * \mathrm{p}<0.01$, n.s. non relevant

(The figures apply only to the group of subjects 50 or older with stable jobs).

\section{Conclusion}

Public policy developed since the 1980s in France as in Belgium has fundamentally changed the view of retirement in society and by extension the associated models or norms, thus creating, alongside the then established systems, new approaches which are seen as just as legitimate.

However, this is not sufficient in itself to explain the incredible surge towards early retirement. Other factors are at work, in particular the utilization of other normative imperatives: self-realization, personal growth, and the need to do something "different” in life! This tidal shift in society helps us to better understand the phenomenon: the individual no longer expresses their individuality through only one facet of their life but composes elements and facets of their life into a whole through various levels of symbolic participation. These multiple facets allow the person to keep a certain perspective as regards their professional investment and other aspects of self realization. Looked at in this way, the end of career is seen as a special time used to reassert or redefine one's identity through other kinds of activity, either within the family circle or outside it, for example, through volunteer work. The older unemployed status established in the 80s in Belgium contributed to the well-being of this specific category of unemployed people.

But the question of retirement is complex and multidimensional: it engages the individual in their relationship to the world, thus, to the very centre of society's underlying principles and mechanisms. This paper has also tried to show how early retirement is not simply a desire to escape, but can also be explained as an aggression against the person by the work world. Leaving professional life early thus seems more to be a case of necessity, in fact not a choice at all, but an obligation, or even a sacrifice and must be seen in the perspective of professional duties and their evolution. So while the older worker could, up until now, benefit from certain accommodations at work (Pailhé, 2005), recently intensified work and transformed management methods condemn them, together with their younger colleagues: age is no longer of any protection! 
As for the choice of early retirement and in the reasons for this choice, the importance of health, and in particular of stress, is undeniable. This problem could well increase as we see the conditions that young workers are subjected to be worse and worse and can even put their health in danger. Today's youth are tomorrow's retirees.

The recent transformations of the social policies towards older workers fall within the framework of the neoliberal conception of social justice and especially the expansion of individualization. First of all, the risks of the precarious existence increase if the government modifies the conditions for early retirement to raise the level of employment. Moreover, individualization is increasingly embedded in strategies for social policy reform, which both promote the illusion of choice and are designed the shape citizens into self-sufficient market actors who provide for their needs and those of their families (Brown, 2005, as cited in Brodie, 2007, p. 103). This definition obviously fits with the evolution of the older workers' status in Belgium.

But the labour market seems definitively closed for the older workers: businesses do not seem to have any interest in keeping older workers nor have they established policies which deal with aging as part of their HR management. So, whether it comes through personal choices or necessity, the question and management of retirement cannot be done solely through a transformation of public policy, even a radical one.

Can't the future of retirement be found in rolling out new policy initiatives that try to reconcile the financial constraints of an aging population with the aspirations of workers? Don't we need to be more creative in the modalities of progressive retirement that would perhaps allow us to properly take into account (dis)continuation of professional life, the individual's aspirations, the transmission of knowledge, and societal constraints? The object of the exercise then becomes how to shift public policy based on early retirement to a progressive retirement policy and not a strategy of forcing people to stay in work.

\section{Notes}

1 For more information, see: www.psbh.ulg.ac.be

2 People come from the North (Dutch language) and the South of Belgium (French language). But there is no relevant difference between French and Dutch people in terms of well-being in this sample.

3 In order to perform logistic regression analysis, the outcome variables were dichotomized. The variable "leisure activities" was dichotomized into never vs. the others. The variable "membership of an association" was dichotomized into membership of any association vs. no membership. The variable "life satisfaction" was dichotomized into unsatisfied subjects vs. the others. The variable "mental health" was dichotomized into with vs. without any mental health problems.

4 Data available from

http://www.consilium.europa.eu/ueDocs/cms_Data/docs/pressData/fr/ec/00100-r1.f0.htm

5 CAPA study, financed jointly by the European Social Fund and the Belgian - Federal Public Service Employment, Labour and Social Dialogue. Survey based on 812 responses obtained in 2005 spread over 12 different sectors of activity: chemical industry, tool and machine manufacture, automotive industry, construction, large retail, hospitality industry, insurance and finance, research and development, public service, education, health care, and social services. 
6 There is no relevant difference between the North and the South of the country. The average age at which people want to retire is similar.

7 Maybe this desire for early retirement will be changed by the important reform of the French retirement system in 2003. These statistics are too recent to analyse this transformation.

\section{References}

Askenazy, P., Cartron, D., de Conick, F., \& Gollac, M. (2006). Organisation et intensité du travail. Toulouse: Octares.

Beck, U. \& Beck-Gernsheim, E. (2002). Individualization: Institutionalized individualism and its social and political consequences. London: Sage.

Blanchet D., \& Debrand T. (2005). Aspiration à la retraite, santé et satisfaction au travail: une comparaison européenne. Insee Première, 1052, 1-4.

Barnay T., \& Jeger F. (2006). Quels dispositifs de cessation d'activité pour les personnes en mauvaise santé? Etudes et Résultats, 492, 1-8.

Bonvin, J.M., \& Burnay, N. (2000). Le tournant procédural des politiques de l'emploi: des situations nationales contrastées. Recherches sociologiques, XXXI (2), 22-32.

Brodie, J. (2007). Reforming social justice in neoliberal times, Studies in Social Justice, 1(2), 93-107.

Brown, W. (2005). Edgework: Critical essays on knowledge and polities. Princeton, NJ: Princeton University Press.

Centre d'études des revenus et des coûts. (1993). Précarité et risque d'exclusion en France. Paris: La Documentation Française

De Nanteuil-Miribel, M., \& El Akremi, A. (2005). La société flexible. Travail, emploi et organisation en débat. Paris: Eres.

Eisenberg, P., \& Lazarsfeld, P.F. (1938). The psychological effects of unemployment. Psychological Bulletin, 35, 358-390.

Elchardus, M., \& Cohen J. (2003). Attitude et attentes en rapport avec la fin de carrière professionnelle. In Rapport partiel 3: les déterminants de la fin de carrière. Leuven:

Esping-Andersen, G. (1990). The three worlds of welfare capitalism. Princeton: Princeton University Press.

Feldman, D.C. (1994). The decision to retire early: A review and conceptualization. The Academy of Management, 19 (2), 285-311.

Friedman, E.A., \& Orbach H.L. (1974). Adjustment to retirement. In S. Arieti (Ed.), American handbook of psychiatry, (2nd ed.), (pp. 609-645) New York, NY: Basic Books.

Gallie, D., \& Paugam, S. (2000). Welfare regimes and the experience of unemployment in Europe. Oxford: Oxford University Press.

Gollac, M., \& Volkoff, S. (2000). Les conditions de travail. Paris: La Découverte, collection Repères.

Gratton B., \& Haug M.R. (1983). Decision and adaptation. Research on Aging. 5, 59-76.

Guillemard, A.-M. (2002). L'Europe continentale face à la retraite anticipée. Revue française de sociologie, 43(2), 333-368.

Guillemard, A.-M. (2003). L'âge de l'emploi. Les sociétés à l'épreuve du vieillissement. Paris: A. Colin, collection U.

Hall, P. (1993). Policy paradigm, social learning and the state. The case of economic policy making in Britain. Comparatives Politics, 25(3), 275-296.

Hall, P. A., \& Soskice, D. (2001). Varieties of capitalism. The institutional foundations of comparative advantage. Oxford: Oxford University Press.

Hardy M. A., \& Hazelrigg L. (1999). A multilevel model of early retirement decisions among autoworkers in plants with different futures. Research on Aging, 21, 275-303.

Hepworth, S. J. (1980). Moderating factors of the psychological impact of unemployment. Journal of Occupational Psychology, 53, 139-148.

Jahoda, M. (1979), The impact of unemployment in the 1930s and the 1970s. Bulletin of the British Psychological Society, 32, 309-314.

Lund T., \& Borg V. (1999). Work environment and self-rated health as predictors of remaining in work five years among Danish employees 35-39 years of age. Experimental Aging Research, 25(4), 429-434. 
McGoldrick A., \& Cooper C. (1980). Voluntary early retirement: taking the decision. Employment Gazette, 859-864.

Molinié, A.-F. (2006). Les salariés quinquagénaires, entre fragilisation et protection. Retraite et Société, 49, $12-37$.

Moos, R. H., Cronkite, R. C., \& Finney, J. W. (1990). Health and daily living form manual (2 ${ }^{\text {nd }}$ ed.). Palo Alto, CA: Mind Garden.

OCDE (1995). Les travailleurs âgés et le marché du travail. Paris: OCDE.

OECD (1998). Maintaining Prosperity in an Ageing Society. Paris: OECD.

Pailhé, A. (2005). Les conditions de travail: quelle protection pour les salariés âgés en France? Population, 1-2, 99-126.

Parker S. (1980). Older workers and retirement. London: HMSO.

Paugam, S, \& Russell, H. (2000). The effects of employment precarity and unemployement on social isolation. In D. Gallie \& S. Paugam (Eds.), Welfare regimes and the experience of unemployment in Europe (pp. 243-264). Oxford: Oxford University Press.

Pierson, P. (1998). Irresistible forces, immovable objects: Post industrial welfare states confront permanent austerity. Journal of European Public Policy, 5 (4), 539-560.

Romans, F. (2007). Transition des femmes et des hommes de la vie active vers la retraite, Statistiques en bref, Population et conditions sociales, 97 Luxembourg: Eurostat.

Rosenberg, M. (1965). Society and the adolescent self-image. Princeton, NJ: Princeton University Press.

Saurel-Cubizolles, M.-J., Bardot, F., Berneron, B., Derriennic, F., Fromet, M., Lasfargues G., Minois, M. C., Monfort, C., Robida, C., \& Rondeau du Noyer, C. (1999). In Cassou et al. (Eds), Travail, santé et Vieillissement. Relations et évolutions (pp. 53-66). Toulouse: Editions Octarès.

Schultz, K.S., Morton, K.R., \& Weckerle, J.R. (1998). The influence of push and pull factors on voluntary and involuntary early retirees' retirement decision and adjustment . Journal of Vocational Behavior, 53, 45-57.

Simoens, D. (1980). Hoe pijnloos is de crisis? Kritische analyse van de ontwikkeling van de wetgeving over de sociale zekerheidsprestaties (1976-1979). In Crisiswetgeving en sociale Zekerheid (70-82). Antwerp: Kluwer.

Szinovacz, M. E., \& De Viney, S. (2000). Marital characteristics and retirement decisions. Research on Aging, 22, 470-498.

Van Solinge, H., Henkens, K. (2005). Couples' adjustment to retirement: A multi-actor panel study. Journal of Gerontology: Social Sciences, 60B, S11-S20.

Walker A. (1985). Early retirement: Release or refuge from the labour market, The Quarterly Journal of Social Affairs, 1(3), 211-229. 